\title{
PEMANFAATAN PUSAKA BUDAYA PURA TIRTA EMPUL SEBAGAI DAYA TARIK WISATA DI BALI
}

\author{
I Ketut Setiawan
}

\author{
Jurusan Arkeologi Fakultas Sastra Universitas UDAYANA
}

\section{Pendahuluan}

Pusaka budaya (beritage) dewasa ini telah mendapat perhatian yang luas. Tumbuhnya kesadaran tentang perlunya penyelamatan benda budaya yang merupakan bukti sejarah masa lalu, dan di sisi lain, adanya peluang ekonomi pariwisata yang memanfaatkan benda budaya tersebut, melahirkan berbagai upaya pelestarian, pengembangan, dan pemanfaatan untuk kepentingan peningkatan kehidupan masyarakat. Jika benda-benda tersebut dikelola secara baik dan profesional, sebagai bagian dari suatu kebudayaan, pusaka budaya bisa menjadi alat pemberdayaan bagi pihak-pihak yang terkait, yaitu pemerintah selaku pemegang kebijakan politik, pengusaha dalam bidang ekonomi, dan masyarakat sebagai pemilik kebudayaan.

Pura Tirta Empul yang terletak di Desa Manukaya, Tampaksiring, Gianyar, Bali adalah salah satu pusaka budaya yang memiliki ciri khas dan keunikan bila dibandingkan dengan tinggalan budaya lainnya, sehingga sangat menarik para wisatawan, lebih-lebih didukung dengan tetap difungsikan-nya sebagai tempat suci, tempat persembahyangan umat Hindu (living monument). Tidak mengherankan, Pura Tirta Empul merupakan sebuah daya tarik wisata yang cukup banyak menyerap pengunjung dan menjadikannya sebagai salah satu tujuan wisata unggulan di Kabupaten Gianyar, selain Gua Gajah dan Gunung Kawi. Pusaka budaya pura ini telah diajukan sebagai Warisan Budaya Dunia.

Sejak Pura Tirta Empul menjadi salah satu tujuan wisata, maka komersialisasi budaya tidak dapat terhindarkan. Komodifikasi Pura Tirta Empul dalam konteks pariwisata global menjadi hal yang menarik untuk diteliti lebih mendalam terkait dengan sosial budaya dan segala aspek kehidupan masyarakat pendukungnya. Kenyataan menunjukkan bahwa kedatangan wisatawan baik lokal maupun asing sebagai konsumen telah membawa pengaruh terhadap sosial ekonomi masyarakat. Pura Tirta Empul sebagai daya tarik wisata dikomodifikasi untuk mendapatkan keuntungan ekonomi. Hal tersebut memunculkan budaya konsumerisme dan kapitalisme yang dapat menimbulkan komodifikasi pada setiap aspek kehidupan masyarakat. Para kapitalis menggunakan segala cara untuk mengkomersialkan seluruh ranah kehidupan dan ranah kebudayaan, termasuk pusaka budaya Pura Tirta Empul. Globalisasi menyebabkan fungsi pura berkembang, tidak saja berfungsi sakral tetapi juga berfungsi ekonomi dalam kaitannya dengan nilai-nilai kehidupan masyarakat. Adanya kepentingan selera pasar telah mengakibatkan terjadinya pergeseran pemaknaan dan pendefinisian terhadap sakralitas pura, pergeseran nilai terhadap pemahaman pura, serta perubahan perilaku dan praktik-praktik budaya masyarakat Desa Manukaya.

\section{Komodifikasi Budaya}

Proses modernisasi melalui pembangunan yang kapitalis atau membela kepentingan pemodal dapat menyebabkan komodifikasi. Komodifikasi adalah proses yang diasosiasikan dengan kapitalisme di mana objek, kualitas, dan tanda-tanda diubah menjadi komoditas, yaitu sesuatu yang tujuan utamanya adalah untuk dijual di pasar (Barker, 2005 : 517). Komoditas dipahami sebagai suatu hasil produksi yang dibuat untuk ditukar di pasar. Dengan kata lain, komoditas adalah segala sesuatu yang diproduksi untuk dijual. Akibat ekonomi uang yang berdasarkan atas spirit menciptakan keuntungan sebanyak-banyaknya mengakibatkan munculnya komodifikasi di berbagai sektor kehidupan.

Orientasi pencarian keuntungan pada masyarakat kapitalis menyebabkan terciptanya produkproduk beragam dan luas. Akhirnya pada masyarakat pascamodern komoditi telah merambah ke berbagai sektor kehidupan dan ranah kebudayaan (Lury, 1998 : 64). Gejala ini oleh penganut postrukturalis disebut sebagai "merkantilisme", yaitu berubahnya status segala wacana, termasuk pengetahuan, pendidikan, dan informasi menjadi komoditi (Piliang, 2006 : 296). Fenomena demikian menjadikan komoditas tidak semata-mata terhenti pada nilai tukar (exchange value) dan nilai guna (use value), namun sudah sampai ke nilai tanda (sign value) (Baudrillard, 1981: 18).

Komodifikasi sudah merambah ke seluruh sektor pariwisata dan sistem kapitalis. Dalam dunia 
pariwisata, komodifikasi secara sadar atau tidak sadar telah menyentuh langsung pada makna-makna kebudayaan, lebih-lebih ketika melibatkan atau memanfaatkan simbolsimbol, ikon-ikon seni, budaya, dan agama. Dengan penggunaan teknologi media, komodifikasi sudah menjadi suatu ritual usaha ekonomi. Fenomena merebaknya industri kebudayaan untuk publik seperti menjamurnya majalah populer, televisi swasta, kawasan wisata, pusat hiburan, dan perbelanjaan modern menempatkan Bali sebagai masyarakat komoditas (Darmadi, 2006:67-68).

Dalam pengembangan pariwisata yang memanfaatkan pusaka budaya atau tinggalan arkeologi (artefak, fitur, situs) harus digarisbawahi bahwa pariwisata pusaka budaya merupakan manifestasi dari komodifikasi kebudayaan (comodification of culture). Hancurnya atau hilangnya batas-batas antara kebudayaan dan ekonomi adalah sebagai sebuah penanda penting posmodernitas (Richards, 1996 : 262 - 263). Komodifikasi tidak sematamata dilakukan oleh para pelaku ekonomi, seperti pemodal pariwisata, masyarakat lokal pun berpotensi dan bahkan sering melakukannya.

Globalisasi telah menjadi kekuatan besar pada dewasa ini. Pasar dalam hal ini muncul sebagai kekuatan dalam membangun dunia kehidupan sehari-hari. Dengan kata lain, pasar menjadi kekuatan dominan dalam pembentukan nilai dan tatanan sosial. Pasar telah memperluas orientasi masyarakat dan mobilitas batasbatas sosial budaya. Pasar sekaligus menguburkan batasbatas itu akibat berubahnya orientasi ruang dalam masyarakat (Appadurai, 1994 : 49).

Pusaka budaya Pura Tirta Empul selain sebagai tempat suci juga dimanfaatkan sebagai modal pengembangan pariwisata, merupakan suatu proses komodifikasi, yaitu dalam posisinya sebagai bagian dari sistem pembangunan daerah. Untuk itu, proses tersebut dapat dijelaskan dengan teori komodifikasi, karena ada upaya secara sengaja dan penuh kesadaran untuk menjadikan produk budaya tersebut menjadi barang dagangan yang siap dijual bagi wisatawan. Pura Tirta Empul mengalami proses komodifikasi karena menjadi komoditas. Menurut Barker (2005 : 408), komoditas adalah suatu yang tujuan utamanya adalah untuk dijual di pasar. Hancurnya batas-batas budaya dan ekonomi, sebagaimana yang sudah lama terjadi dalam praktikpraktik kepariwisataan dengan pariwisata budayanya, menjadi penanda penting posmodernitas.
Sejalan dengan proses komodifikasi, produk budaya Pura Tirta Empul sebagai salah satu bagian dari ikon budaya masyarakat Desa Manukaya pun mengalami dinamika dalam dialektika sakral dan profan. Di satu sisi masyarakat dengan berbagai komponen di dalamnya berusaha melestarikan dengan tetap mempertahankan nilai-nilai kesakralan, tetapi di sisi lain adanya pengaruh berbagai faktor, khususnya faktor ekonomi untuk meningkatkan kesejahteraan, menjadikan masyarakat pendukung budaya Pura Tirta Empul dilematis.

Kedatangan para wisatawan dengan berbagai latar belakang budaya ke Pura Tirta Empul sesungguhnya secara tidak langsung telah menggeser nilai-nilai sakral ke nilai profan. Pergeseran Pura Tirta Empul dari sakral ke profan tidak dengan sendirinya terjadi, tetapi melalui suatu proses pertentangan-pertentangan, sejalan dengan perubahan sosial budaya masyarakat. Selanjutnya, jika dikaitkan dengan perkembangan zaman dengan majunya ilmu pengetahuan dan teknologi, serta terbukanya aksesakses pengaruh luar terhadap pandangan hidup masyarakat Desa Manukaya, maka perlahan-lahan, disadari atau pun tidak, mulai terjadi pergeseran nilai-nilai tradisi.

Potensi budaya yang dimiliki Pura Tirta Empul sebagai daya tarik wisata, masuk ke dalam industri budaya. Strinati (2003 : 67-68) memberikan penjelasan bahwa masuknya produk budaya ke dalam industri budaya, berarti dia tunduk kepada hukum ekonomi sehingga dia berubah menjadi budaya massa. Perubahan ini berimplikasi terhadap aura kebudayaan yang tidak lagi mengikuti kehendak pembuatnya, tetapi tunduk kepada mekanisme pasar. Akhirnya produk budaya terlepas dari pengalaman estetis dan terkena fetisisme komoditi sehingga nilai gunanya dilepaskan, diganti dengan nilai tukar.

\section{Dampak Terhadap Kehidupan Sosial Ekonomi}

Dewasa ini, globalisasi secara perlahan-lahan membuat dunia menjadi satu dengan yang lain, batas-batas politik, budaya, ekonomi, menjadi semakin kabur serta tampak kesalingberhubungan. Zaman terus berubah, dunia terus bergerak, dan teknologi komunikasi menjadi serba canggih, sehingga tidak menutup kemungkinan terjadi mobilitas sosial (Abdullah, 2007). Pergerakan orang (pariwisata) demikian cepat membawa kapitalisme telah masuk ke dunia bisnis kebudayaan. Komodifikasi budaya terjadi karena pasar cenderung memperlakukan budaya 
sebagai barang dagangan ketimbang memperlakukan budaya sebagai sebuah medan nilai.

Selera ideologi pasar telah merajalela ke sendisendi budaya tradisi dengan arus global kontemporernya menghanyutkan nilai-nilai estetik fondasi kehidupan masyarakat Desa Manukaya yang dipresentasikan melalui pusaka budaya Pura Tirta Empul. Komodifikasi Pura Tirta Empul menggugat akar budaya manusia yang diterminasinya kepada filosofi, jatidiri, dan pandangan hidup masyarakat dewasa ini dan masa yang akan datang, selalu dibayangi oleh kekuatan globalisasi (Atmaja, 2008). Oleh karena itu, ideologi selalu melatarbelakangi penilaian tentang kebenaran sebagai kondisi sosial, seperti Pura Tirta Empul sebagai tempat suci ikut bergeser dan didekonstruksi. Dekonstruksi ideologi membongkar dan membangun kembali ideologi baru yang sesuai dengan pergerakan zaman. Dekonstruksi di sini dimaksudkan membongkar kemapanan sedemikian rupa, sehingga menciptakan suatu permainan tanda yang tanpa akhir dan tanpa makna akhir. Konsep dekonstruksi sangat lekat dengan pandangan hipersemiotika yang dikembangkan oleh Derrida dalam upaya merekonstruksi makna. Dekonstruksi merupakan satu pendekatan kunci postmodernisme terhadap pengetahuan, karena mengarahkan perhatian pada berbagai perubahan yang terjadi dalam budaya kontemporer (Featherstone, 2005 : 14).

Idelogi yang mendasari komodifikasi Pura Tirta Empul dalam konteks pariwisata global merujuk dan mengarah pada ideologi pasar. Hal ini terjadi karena ada kesempatan dan peluang, sehingga masyarakat pemilik kebudayaan Pura Tirta Empul termotivasi melahirkan kreativitas dalam menyambut "pasar" peradaban masyarakat global, seperti industri pariwisata yang berciri kekuatan kapitalisme dibidang ekonomi. Pura Tirta Empul yang semula merupakan tempat suci, kemudian merambah, dimanfaatkan sebagai daya tarik wisata. Kedua sisi itu tampak berlawanan, tetapi berjalan berdampingan saling melengkapi dan memperkokoh eksistensi masingmasing. Sekat yang menjadikan Pura Tirta Empul sebagai tempat suci dan daya tarik wisata dibangun oleh kebiasaan atau pengalaman manusia yang sifatnya ritual dan kepentingan praktis untuk memperoleh keuntungan ekonomi.

Manfaat positif pariwisata bagi masyarakat Desa Manukaya pada umumnya, antara lain adalah meningkatkan lapangan usaha, meningkatnya lapangan kerja, meningkatnya pendapatan masyarakat, dan mendorong pertumbuhan sektor perdagangan. Masyarakat Desa Manukaya dan sekitarnya sangat merasakan manfaat positif pariwisata tersebut. Hal ini memberi inspirasi kepada sebagian penduduk untuk membuka kios yang menjual makanan, minuman dan cenderamata di sekitar areal Pura Tirta Empul (Ardika, 2007).

Harapan untuk hidup lebih baik, merupakan orientasi masyarakat Manukaya ke masa depan. Harapan tersebut selain didukung oleh potensi-potensi internal, juga didukung oleh faktor-faktor eksternal. Potensi internal bersumber dari masyarakat itu sendiri karena adanya sesuatu yang dianggap sudah tidak lagi memuaskan atau keinginan untuk lebih baik daripada keadaan sebelumnya. Sementara faktor-faktor eksternal di antaranya adalah program-program pemerintah dalam bentuk penyuluhan, promosi dan tentu saja budaya pariwisata. Rendahnya pendapatan petani dari hasil pertanian, pada akhirnya menimbulkan ketidakpuasan terhadap kondisi tersebut. Upaya untuk mengatasinya adalah menggantungkan variasi-variasi usaha yang ada di luar sektor pertanian, khususnya sektor pariwisata.

\section{Dampak Terhadap Kehidupan Sosial Budaya}

Pura Tirta Empul di Desa Manukaya pada awalnya bukan produk budaya yang sengaja diciptakan untuk tujuan komersial. Namun, dalam perkembangan masa kini Pura Tirta Empul mengalami komodifikasi yang mengarah komersialisasi karena ditata untuk memenuhi selera pasar. Hal seperti itu menurut Sifullah (1994 : 12) menunjukkan adanya kaitan antara tradisi dan modernitas yang telah diubah menjadi hubungan komersial. Kepentingan kapitalisme menjadikan Pura Tirta Empul sebagai alat komoditas yang bernilai jual. Dalam hal ini, pasar turut menentukan arah komodifikasi Pura Tirta Empul dalam penampilannya, yakni objek, kualitas bahan, ornamen atau ragam hias, pewarnaan akhir, dan penataan yang semua dikemas untuk dijadikan komoditas dengan tujuan utamanya adalah memenuhi selera pasar.

Berdasarkan asumsi dasar mengenai keterkaitan antara komoditas Pura Tirta Empul dengan kehidupan sosial budaya masyarakat, maka Pura Tirta Empul sebagai produk budaya manusia merupakan hasil kebudayaan dari suatu sistem yang terdiri atas unsurunsur kebudayaan yang saling terkait, khususnya antara 
unsur seni, religi, dan komersial. Unsur-unsur seni, relegi, dan komersial tidak berdiri sendiri, tetapi saling berhubungan, saling terkait, atau bahkan ada saling bergantung antara satu dengan yang lainnya. Keadaan saling terkait tersebut berorientasi pada kehidupan atau kelangsungan hidup suatu sistem dalam satu kesatuan secara menyeluruh (Bagus, 1975).

Pariwisata merupakan kegiatan yang secara langsung menyentuh dan melibatkan masyarakat, sehingga memberikan pengaruh terhadap masyarakat setempat. Bahkan pariwisata mempunyai energi pendobrak yang kuat dan mampu membuat masyarakat setempat mengalami perubahan, baik ke arah perbaikan maupun ke arah penurunan (degradasi) dalam berbagai aspek.

Dampak sosial budaya menurut Cooper (1993 : 26) muncul karena industri pariwisata melibatkan tiga hal, yaitu wisatawan, masyarakat setempat, dan hubungan wisatawan dan masyarakat. Dampak sosial budaya muncul apabila terjadi interaksi antara wisatawan dan masyarakat ketika (1) wisatawan membutuhkan produk dan membelinya dari masyarakat disertai tuntutan-tuntutan sesuai dengan keinginannya, (2) pariwisata membawa hubungan yang informal dan tradisional menjadi konsumsi ekonomi. Pengusaha pariwisata mengubah sikap spontanitas masyarakat menjadi transaksi komersial, dan (3) wisatawan dan masyarakat bertatap muka dan bertukar informasi atau ide, menyebabkan munculnya ide-ide baru.

Terkait dengan penelitian ini, dampak komodifikasi Pura Tirta Empul dalam konteks pariwisata global terhadap sosial budaya masyarakat setempat tidak dapat secara cepat terlihat, karena perubahan yang terjadi dalam masyarakat tidak terjadi seketika, tetapi melalui proses. Hasil pengamatan di lapangan menunjukkan bahwa dampak komodifikasi Pura Tirta Empul terhadap kehidupan sosial budaya masyarakat Manukaya cenderung bersifat negatif yang dapat mendatangkan kerugian, seperti terjadinya komersialisasi tempat suci, kaburnya identitas dan nilai sejarah, dan tercemarnya tempat suci serta munculnya gejala hiperspiritualitas.

\section{Kesimpulan}

Berdasarkan hasil penelitian di atas, dapat ditarik beberapa simpulan sebagai berikut. Komodifikasi Pura Tirta Empul telah mengalami proses sejarah yang panjang, diawali dengan adanya gejala komodifikasi yang cenderung mengarah pada pergeseran nilai yang dilakukan oleh masyarakat dalam memproduksi dan mendistribusikan dalam upaya memenuhi permintaan pasar. Gejala komodifikasi seperti dialektika sakral dan profan atau degradasi kesucian menjadikan Pura Tirta Empul hadir dalam bentuk tampilan yang indah, namun perlahan-lahan dan pasti kesakralan diabaikan. Bentukbentuk komodifikasi Pura Tirta Empul terjadi sejak proses produksi, distribusi, dan konsumsi, sebagai satu kesatuan. Produksi dan distribusi bentuk komodifikasi pura dilakukan atas inisiatif masyarakat sendiri dan secara kelembagaan dengan Pemerintah Kabupaten Gianyar, di mana Pura Tirta Empul yang sebelumnya bukan komoditas kemudian diperlakukan sebagai komoditas yang diperjualbelikan untuk mendapatkan keuntungan ekonomi.

Dampak komodifikasi Pura Tirta Empul adalah implikasi yang kuat berkaitan dengan bergesernya nilai magis-religius. Komodifikasi Pura Tirta Empul berdampak pada aspek sosial ekonomi dan sosial budaya. Dampak terhadap aspek sosial ekonomi adalah meningkatnya taraf kesejahteraan kehidupan masyarakat Desa Manukaya. Uang yang diperoleh dari penyedaiaan fasilitas wisata kepada wisatawan dikembalikan kepada adat dan tradisi, seperti pelaksanaan upacara-upacara keagamaan serta sarana dan prasarana yang mendukungnya. Wujudnya adalah pelaksanaan upacara agama secara lebih teratur dan berkualitas, di samping memperbaiki pura sesuai dengan kemampuan ekonomi masyarakat itu sendiri. Sedangkan dampak terhadap sosial budaya cenderung kurang menguntungkan karena telah terjadi komersialisasi tempat suci. Komersialisasi tempat suci dapat mengakibatkan bergesernya atau menurunnya nilai-nilai religius tempat suci tersebut.

\section{Daftar Pustaka}

Abdullah, Irwan, 2007. Konstruksi dan Reproduksi Kebudayaan. Yogyakarta: Pustaka Pelajar.

Adorno, Theodor. 1991. The Culture Industry : Selected Essay on Mass Culture Routledge: London.

Agger, Ben. 2007. Teori Sosial Kritis, Praktik Penerapan dan Implikasinya. Yogyakarta : Penerbit Kreasi Wacana.

Althusser, L. 2004. Tentang Ideologi : Marxisme Strukturalis, Psikoanalisis, Cultural Studies (Terjemahan). Yogyakarta : Jalasutra.

Appadurai, Arjun. 1996. Modernity at Large : Cultural 
Dimensions of Globalization. London : Routledge.

Ardika, I Wayan. 2007. Pusaka Budaya dan Pariwisata. Denpasar: Pustaka Larasan.

Astra, I Gede. Semadi. 2004. "Revitalisasi Kearifan Lokal dalam Memperkokoh Jatidiri Bangsa di Era Global" Dalam Politik Kebudayaan dan Indentitas Etnik. Denpasar. Fakultas Sastra Universitas Udayana dan Bali Mangsi Press.

Atmaja, Nengah Bawa. 2008. "Ideologi Tri Hita Karana Noeliberalisme $=$ Vilanisasi Radius Suci Pura (Perspektif Kajian Budaya") Dalam Dinamika Sosial Masyarakat Bali. Denpasar : Fakultas Sastra Unud.

Bagus, I Gusti Ngurah. 1971. "Kebudayaan Bali” Dalam Manusia dan Kebudayaan di Indonesia. Hal 279299. Jakarta: Penerbit Jambatan.

1975. Bali Dalam Sentuhan Pariwisata. Denpasar.

Barker, Chris. 2005. Cultural Studies Teori dan Praktik (terjemahan : Tim Kunci Cultural Studies Centre). Yogyakarta : Bentang (PT. Bentang Pustaka).

Baudrillard, Jean P. 1981. For Critique fot The Political Economy of the Sign. United States : Telos Press.

Bourdieu, Pierre. 1991. Language and Symbolic Power. Cambridge : Polity.

Coover, C. et.al. 1993. Tourism Principles and Pratice. London : Pitman Publishing.

Darmadi, IGN. Eka. 2006 "Pariwisata Antara Kewirausahaan dan Kewirabudayaan". Jurnal Kajian Budaya. Vol. 3. No. 5. Januari. Hal. 67-87.

Fairclough N. 1995. Discourse and Social Change. Cambridge : Polity Press.

Featherstone, Mike, 1991. Consumer Cultural and Post Modernism. London. Sage Publication.

2008. Posmodernisme dan Budaya Konsumen (terjemahan). Yogyakarta: Pustaka Pelajar.

Geriya, I Wayan. 1993 “ Model Interaksi Kebudayaan dan Industri Pariwisata Pada Masyarakat Bali”. Dalam Kebudayaan dan Kepribadian Bangsa. Denpasar: PT. Upada Sastra.

2008. Transformasi Kebudayaan Bali Memasuki AbadXXI. Surabaya: Penerbit Paramita.

Giddens, Anthony. 1991. Modernity and Self Identity. Cambridge : Polity Press.

Gramsci, Antonio. 1971. Selections from Prison Note Books. New York: International Publisher.

Lubis, Akhyar Yusuf. 2006. Dekonstruksi Epistimologi Modern, dari Posmodermisme, Teori Kritis, Poskolonialisme Hingga Cultural Studies. Jakarta : Pustaka Indonesia Satu.
Lury, Celia. 1998. Budaya Konsumen. Jakarta : Yayasan Obor Indonesia.

Picard, Michel. 2006. Bali Pariwisata Budaya dan Budaya Pariwisata. Jakarta : Kepustakaan Populer Gramedia.

Piliang, Yasraf Amir. 1999. Hiper Realitas Kebudayaan. Yogyakarta: LKIS.

2006a. Dunia yang Dilipat Tamasya Melampaui Batas-batas Kebudayaan. Bandung : Percetakan Jalasutra.

2006b. "Cultural Studies dan Posmodernisme" : Isyu, Teori, dan Metode" hal. 19-34. vol. 3 No.6. Juli. Denpasar : Program S2 dan S3 Kajian Budaya Universitas Udayana.

Pitana, I Gede. 2006, "Industri Budaya dalam Pariwisata Bali : Reproduksi, Presentasi, Konsumsi dan Konservasi Kebudayaan”. Dalam Bali Bangkit Kembali. Kerjasama Departemen Kebudayaan dan Pariwisata Republik Indonesia dan Universitas Udayana.

Ratna, Nyoman Kutha. 2005. Sastra dan Cultural Studies Representasi Fiksi dan Fakta. Yogyakarta : Pustaka Pelajar.

Richard, G. 1996. "Production and Consumption of European Cultural Tourism". Dalam Annal of Tourism Research. Vol. 23. No. 2. hal.261-283.

Sedyawati, Edi, 2002. "Pembagian Peranan dalam Pengelolaan Sumberdaya Budaya" dalam Manfaat Sumberdaya Arkeologi Untuk Memperkokoh Integrasi Bangsa. Denpasar : PT. Upada Sastra

2007. Budaya Indonesia, Kajian Arkeologi, Seni, dan Sejarah. Jakarta: PT. Raja Grafindo Persada.

Sifullah. 1994. "Mobilitas Penduduk dan Perubahan di Pedesaan", dalam Majalah Prima, No. x, Edisi Juli, hal. 32-41.

Storey, John. 2003. Teori Budaya dan Budaya Pop, Memetakan Lanskop Konseptual "Cultural Studies" (Terjemahan). Yogyakarta : Penerbit Qalam.

2007. Cultural Studies dan Kajian Budaya Pop. Pengantar Paling Komprehensif Teori dan Metode (Terjemahan). Yogyakarta: Jalasutra.

Strinati, Dominic. 2007. Popular Cultural: Pengantar Menuju Teori Budaya Populer (Terjemahan). Yogyakarta. PenerbitJejak. 